\title{
Pengembangan Multimedia Pembelajaran Interaktif untuk Meningkatkan Hasil Belajar IPS
}

\author{
Abdurrahman \\ Program Studi Teknologi Pendidikan, Universitas Pendidikan Ganesha \\ abdurrahman@undiksha.ac.id \\ I Nyoman Jampel \\ Program Studi Teknologi Pendidikan, Universitas Pendidikan Ganesha \\ jampel@undiksha.ac.id \\ I Gde Wawan Sudatha \\ Program Studi Teknologi Pendidikan, Universitas Pendidikan Ganesha \\ igdewawans@undiksha.ac.id
}

\begin{tabular}{l} 
A R T I C L E I N F O \\
\hline Article history: \\
1 Januari 2020 Received in \\
revised form \\
30 Mei 2020 \\
Accepted 30 Juni 2020 \\
Available online \\
15 Juli 2020 \\
\hline Kata Kunci: \\
ADDIE, Multimedia, Hasil \\
Belajar \\
Keywords: \\
ADDIE, Multimedia, \\
Learning Outcome
\end{tabular}

\begin{abstract}
ABSTRAK
Kurangnya media pembelajaran yang digunakan oleh guru dalam menyampaikan materi pelajaran IPS terpadu mengakibatkan siswa pasif dalam mengikuti kegiatan pembelajaran. Tujuan penelitian ini adalah menjelaskan rancang bangun pengembangan multimedia interaktif dengan model pengembangan ADDIE. Metode pengumpulan data yang digunakan adalah observasi, wawancara, kuesioner, dan tes. Analisis data yang digunakan adalah teknik deskriptif kualitatif, deskriptif kuantitatif dan analisis statistik inferensial dengan dilakukan uji prasyarat. Validitas media diuji coba kepada ahli isi mata pelajaran diperoleh $96,00 \%$
\end{abstract} dalam kategori sangat baik, ahli media pembelajaran diperoleh $78,00 \%$ dalam kategori baik, uji coba perorangan diperoleh $86,88 \%$ dalam kategori sangat baik, kelompok kecil diperoleh 94,33\% dalam kategori sangat baik dan uji coba lapangan diperoleh 87,11 dalam kategori sangat baik. Berdasarkan uji efektivitas terdapat perbedaan yang signifikan antara hasil pretest dan posttest. Dengan demikian dapat disimpulkan bahwa multimedia pembelajaran interaktif dapat meningkatkan hasil belajar siswa pada mata pelajaran IPS Terpadu sehingga multimedia pembelajaran interaktif efektif digunakan dalam proses pembelajaran sehingga multimedia pembelajaran intaraktif efektif digunakan dalam proses pembelajaran.

\begin{abstract}
The lack of learning media used by teachers in delivering integrated social studies subject material results in passive students participating in learning activities. The purpose of this research was to explain the design of interactive multimedia development with the ADDIE development model. Data collection methods used was observation, interviews, questionnaires, and tests. Data analysis used was qualitative descriptive technique, quantitative descriptive and inferential statistical analysis with prerequisite tests. The validity of the media was tested on subject matter experts obtained $96.00 \%$ in the excellent category, learning media experts obtained $78.00 \%$ in the good category, individual trials were obtained $86.88 \%$ in the very good category, small groups obtained $94.33 \%$ in the excellent category and field trials obtained 87.11 in the excellent category. Based on the effectiveness test there was a significant difference between the results of the pretest and posttest. Thus it could be concluded that interactive learning multimedia could improve
\end{abstract}


student learning outcomes in Integrated Social Studies subjects so that interactive learning multimedia was effectively used in the learning process so that interactive learning multimedia was effectively used in the learning process.

\section{PENDAHULUAN}

Ilmu Pengatahuan Sosial (IPS) adalah studi integratif tentang kehidupan manusia dalam berbagai dimensi ruang dan waktu dengan segala aktivitasnya. Dalam rumusan yang lain IPS didefinisikan sebagai kajian yang terkait dengan kehidupan sosial kemasyarakatan beserta lingkungannya untuk kepentingan pendidikan dan pembentukan para pelaku sosial (Surahman \& Mukminan, 2017). Menurut Sapriya (dalam Saputra \& Yuniarita, 2017), mata pelajaran IPS merupakan muatan wajib yang harus ada dalam kurikulum pendidikan dasar dan menengah. Pembelajaran IPS memiliki manfaat yang sangat besar bagi kehidupan manusia, dengan pembelajaran IPS siswa dapat meningkatkan pengetahuan, keterampilan, dan sikap dalam menyikapi perubahan sosial dilingkungan sekitarnya dalam hal ini pembelajaran IPS sangat berkaitan dengan pola kehidupan manusia baik dalam menentuhan kebutuhan hidup maupun sikap sosial yang berlangsung dalam kehidupan kemasyarakatan. Dalam upaya meningkatkan pengetahuan, keterampilan dan sikap siswa, guru harus mampu menyampaikan dan memberi contoh kepada siswa terkait materi IPS yang dipelajari di kelas dengan baik sehingga siswa mampu mengimplementasikan pengetahuannya dalam lingkungan masyarakat.

Guru memiliki peran penting dalam proses pembelajaran karena guru punya tanggung jawab untuk mengelola, merancang, melaksanakan dan mengevaluasi pembelajaran, sehingga guru menjadi salah satu penentu keberhasilan proses pembelajaran. Implikasinya adalah guru perlu memfasilitasi peserta didik terutama yang berkebutuhan khusus dalam proses pembelajaran dikarenakan kondisi dan kemampuan mereka yang terbatas. Oleh karena itu peran guru dalam menjembatani antara kebutuhan belajar dan tujuan pembelajaran menjadi penting (Septiana, 2017). Dalam perannya untuk mmfasilitasi pembelajaran siswa, guru dapat menggunakan beragam metode pembelajaran dalam menyampaikan materi pelajaran kepada siswa. Berkaitan dengan hal ini penggunaan metode yang tepat akan memudahkan siswa dalam menyerap ilmu pengetahuan. Banyak metode yang bisa digunakan oleh guru dalam upaya menyampaikan materi pembelajaran disekolah, salah satunya adalah dengan menggunakan media pembelajaran. Sadiman, dkk (dalam Cahdriyana \& Richardo, 2016), menyatakan bahwa media adalah segala sesuatu yang dapat digunakan untuk menyalurkan pesan dari pengirim ke penerima sehingga dapat merangsang pikiran, perasaan, perhatian, minat dan perhatian siswa sedemikian rupa sehingga proses belajar terjadi. Media pembelajaran memiliki peran yang sangat strategis dalam mengikuti proses pembelajaran, melalui kreatifitas seorang guru media pembelajaran dapat berkembang menjadi suatu yang menarik dan memotivasi siswa untuk lebih giat mengikuti pelajaran (Mislan \& Santoso, 2019).

Peran guru dalam memfasilitasi proses belajar siswa ini pada dasarnya adalah salah satu faktor yang mempengaruhi hasil belajar siswa. Secara umum ada dua faktor yang mempengaruhi prestasi belajar siswa, yaitu faktor internal dan faktor eksternal. Faktor internal adalah faktor yang datangnya dari diri siswa faktor tersebut diantaranya faktor fisiologis (kesehatan, dan keadaan tubuh), psikologis (minat, bakat, intelegensi, emosi, 
kelelahan, dan cara belajar). Sedangkan faktor eksternal merupakan faktor yang datangnya dari luar diri siswa. Faktor tersebut antara lain lingkungan keluarga, lingkungan sekolah, lingkungan masyarakat, dan ligkungan alam.

Agar hasil belajar mahasiswa mencapai hasil yang optimal maka semua faktor tersebut haruslah berkontribusi sinergik satu sama lain. Namun, apa yang semestinya berjalan untuk mencapai hasil belajar yang optimal tidak sesuai dengan kenyataan yang dihadapi. Kegiatan pembelajaran yang berlangsung kerapkali justru masih berjalan menggunakan metode konfensional atau ceramah. Berdasarkan hasil wawancara dengan salah satu guru mata pelajaran IPS Terpadu pada salah satu sekolah terungkap bahwa guru masih belum mampu melaksanakan pembelajaran yang inovtif khususnya yang bertalian dengan mengembangkan media pembelajaran utamanya media pembelajaran berbasis digital. Selain itu guru tidak memahami manfaat dan fungsi media dalam kegiatan pembelajaran sehingga guru lebih memilih untuk menggunakan metode konvensional. Hal tersebut tentu sangat dapat mempengaruhi hasil belajar siswa sebab penerapan metode konvensional cenderung membuat siswa pasif. Penggunaan media pembelajaran akan mempengaruhi minat dan motivasi siswa dalam mengikuti kegiatan pembelajaran. Herawati, (2017) mengatakan bahwa pemakaian media pembelajaran dapat membangkitkan keinginan dan minat yang baru, membangkitkan motivasi, dan rangsangan kegiatan belajar, dan akan membawa pengaruh-pengaruh psikologis terhadap siswa.

Penelitian terdahulu yang bertalian dengan penggunaan media pembelajaran dilakukan oleh Lina Novita, dkk. (Novita et al., 2020). Temuan penelitian ini menunjukkan bahwa terdapat perbedaan hasil belajar yang diajarkan dengan media pembelajaran kartu bergambar dan media pembelajaran konvensional pada peserta didik kelas VA dan VB Sekolah Dasar Negeri Karadenan Kaum Kabupaten Bogor Semester Genap Tahun Pelajaran 2019-2020. Selain itu Rahma Diani, dkk. (Diani et al., 2016) dalam penelitiannya menemukan bahwa terdapat pengaruh model pembelajaran Scramble dengan media video terhadap hasil belajar peserta didik pada materi pengukuran kelas $\mathrm{X}$ MAN 1 Pesisir Barat. Penelitian lain juga dilakukan oleh Dian Kurniawan dan Sinta Verawati Dewi (Kurniawan \& Dewi, 2017) menemukan bahwa dengan pembelajaran menggunakan media Screencast-O-Matic aktivitas mahasiswa selama pembelajaran menunjukkan hasil yang efektif, kemampuan dosen dalam mengelola pembelajaran efektif, respin mahasiswa terhadap pembelajaran media Screencast-O-Matic positif, dan tes hasil belajar yang dilakukan terhadap mahasiswa menunjukkan uji validitas yang valid. Sejalan dengan itu Sri Hayati, dkk (Hayati et al., 2015) dalam penelitiannya menemukan bahwa hasil uji kelayakan kepada ahli dan pengguna didapatkan rata-rata persentase keseluruhan adalah $95,87 \%$ dengan interpretasi sangat baik, hal ini menunjukkan bahwa media Flipbook Fisika berbasis multimedia yang dibuat layak digunakan dalam pembelajaran fisika. Selain itu, media Flipbook Fisika berbasis multimedia dapat meningkatkan hasil belajar peserta didik, dimana nilai rata-rata tes awal 36,11 pada kelas eksperimen sebagai kelas pengguna media meningkat menjadi 84,44 dengan kenaikan 57,23\%. Selain itu penelitian sejenis juga dilakukan oleh Gede Ari Yudasmara dan Desi Purnami (Yudasmara \& Purnami, 2015). Penelitin ini menemukan bahwa media pembelajaran interaktif biologi yang dikembangkan mampu meningkatkan kualitas pembelajaran di SMP Negeri 3 Kintamani. Dari beberapa penelitian ini 
menunjukkan bahwa media pembelajaran juga turut berperan dalam meningkatkan hasil belajar siswa.

Berdasarkan realita diatas, pengembangan inovasi dalam proses pembelajaran sangatlah perlu dilakukan sehingga masalah pembelajaran dapat terpecahkan. Pengembangan media pembelajaran merupakan solusi untuk untuk memecahkan masalah tersebut. Penggunaan media pembelajaran merupakan salah satu kunci sukses pelaksanaan proses belajar mengajar di kelas. Menurut Dhey dan Branch (dalam Qondiaas et al., 2016), media yang digunakan oleh guru dalam menciptakan pengalaman pembelajaran yang berkualitas memiliki pengaruh secara langsung pada prestasi akademik. Media pembelajaran merupakan sarana yang digunakan dalam proses pembelajaran sehingga proses komunikasi dan interaksi dalam pelaksanaan pembelajaran terlaksana dengan lebih menarik. Multimedia pembelajaran interaktif adalah salah satu media yang bisa dijadikan solusi dalam memecahkan masalah tersebut. Multimedia adalah media pembelajaran yang terbangun dari kombinasi teks, gambar, grafik, suara, video, animasi, simulasi secara terpadu dan sinergis dengan bantuan computer atau sejenisnya untuk mencapai tujuan pembelajaran tertentu dimana pengguna dapat secara aktif berinteraksi dengan program. Dengan adanya pengambangan ini diharapkan guru dapat termotivasi untuk menggunakan sarana dan prasarana yang ada disekolah dengan baik. guru dapat mengintegrasikan dengan media yang dapat digunakan dalam mengembangkan media pembelajaran sehingga dapat memberikan suasana baru dalam proses pembelajaran dikelas maupun diluar kelas.

Tujuan dalam penelitian ini adalah untuk mendeskripsikan bagaimana proses pengembangan multimedia pembelajaran interaktif pada mata pelajaran IPS terpadu, selain itu mendeskripsikan tanggapan para uji ahli yaitu uji ahli isi pembelajaran dan uji media pembelajaran dan uji coba terhadap uji coba perorangan, kelompok kecil, dan uji coba lapangan, dan menjelaskan efektivitas multimedia yang dikembangkan untuk mengetahui sejauh mana multimedia yang dikembangkan dapat mempengaruhi hasil belajar siswa kelas VIII di MTs At-Taufiq Singaraja pada tahun ajaran 2019-2020.

\section{METODE PENELITIAN}

Jenis penelitian ini adalah penelitian pengembangan. Menurut Sugiyono (dalam Angko \& Mustaji, 2013), metode penelitian pengembangan adalah metode penelitian yang digunakan untuk menghasilkan produk tertentu dan menguji keefektifan produk tersebut. Produk yang dimaksud dalam penelitian ini berupa multimedia pembelajaran interaktif dengan materi yang berorientasi pada mata pelajaran IPS terpadu. Populasi dalam penelitian ini adalah siswa kelas VIII di MTs At-Taufiq Singaraja yang berjumlah 18 orang siswa. Model yang digunakan dalam penelitian pengembangan multimedia pembelajaran interaktif ini mengacu pada model pengembangan ADDIE. H. Wiphasith (Wiphasith et al., 2016) mengemukakan model ADDIE adalah sebuah model pengembangan yang populer dan siterima secara umum dapat digunakan dalam desain dan pengembangan bahan ajar. Model ini terdiri dari lima tahap kegiatan, yaitu: (1) Analisis (Analysis), (2) Desain (Design), (3) Pengembangan (Development), (4) implementasi (Implementation), dan (5) Evaluasi (Evaluation). 


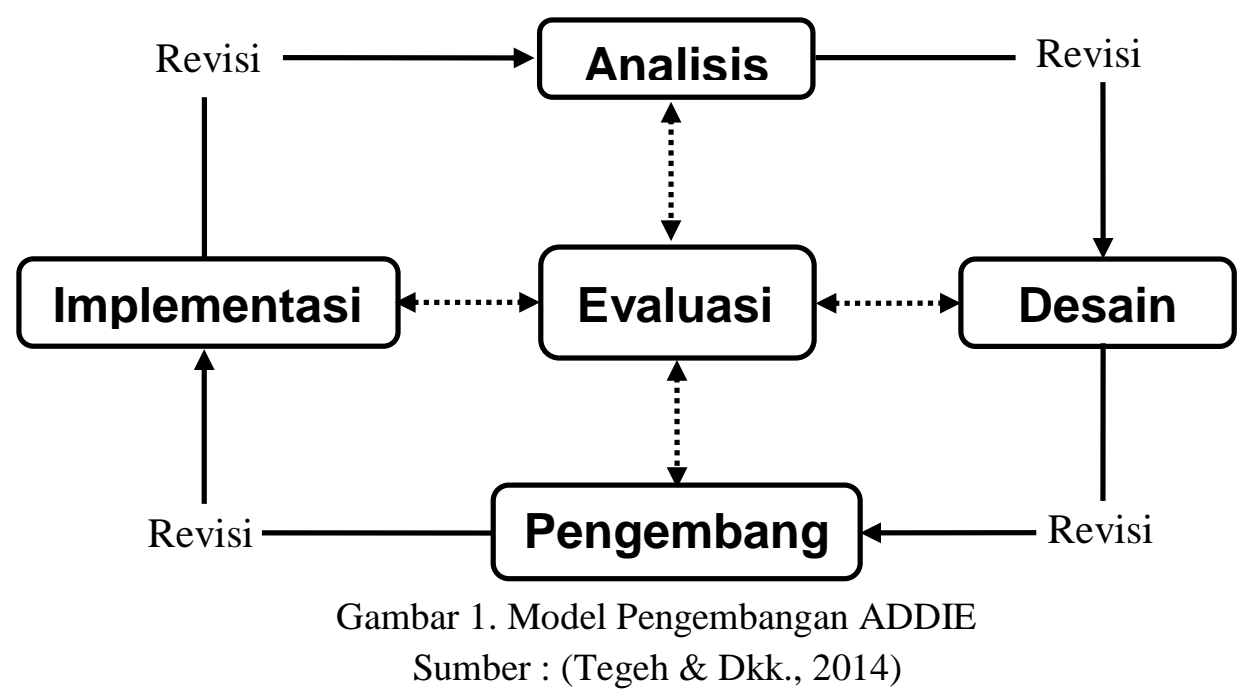

Prosedur pengembangan pada model ADDIE terdiri dari lima tahap, yaitu sebagai berikut.

Pertama Tahap Analisis (Analysis), Tahap yang harus dilakukan sebelum mengembangkan sebuah multimedia adalah melakukan analisis kebutuhan. Pada tahap analisis dilakukan identifikasi masalah, penetapan tujuan intruksional, kriteria siswa, sumberdaya yang tersedia, rekomendasi jenis media, dan penentuan jenis media (Reyvalda et al., 2019). Salah satu cara untuk menentukan hal tersebut adalah dengan melakukan wawancara. Wawancara dilakukan terhadap pihak sekolah yang akan dijadikan tempat penelitian. Subjek yang dapat diwawancarai yaitu, kepala sekolah, guru dan juga siswa.

Selanjutnya hasil wawancara tersebut digunakan sebagai pedoman untuk mencari solusi terhadap permasalahan yang ditemukan. Berdasarkan uraian di atas dan hasil wawancara dengan salah satu guru kelas VIII bernama Bapak Rifki Maulana, S.Pd menunjukkan adanya beberapa permasalahan yaitu Pertama, Kurangnya media pembelajaran yang dapat membantu proses pembelajaran sehingga guru masih menggunakan metode konvensional dalam setiap pembelajaran. Kedua, siswa mengalami kesulitan dalam memahami pelajaran yang disampaikan oleh guru yang disebabkan siswa tidak dapat melihat secara langsung terhadap kejadian suatu proses atau fenomena yang terjadi. Ketiga, Ketertinggalan guru dalam mengelola teknologi informasi sehingga banyak guru yang tidak dapat menggunakan media pembelajaran berbasis digital. Dari masalah yang ada maka dirancanglah sebuah multimedia pembelajaran interaktif. Multimedia ini dirancang sesuai dengan kebutuhan dan permasalahn yang ada disekolah agar dapat memberikan solusi dalam menyelesaikan permasalahan yang ada.

Kedua, Tahap desain (Design), Pada tahap desain didapatkan seluruh informasi dari tahap analisis dan memulai proses kreatif dari merancang bahan ajar berbasis teknologi infoemasi untuk mencapai tujuan pembelajaran (Training) (Isya', 2017). Hasil dari analisis kebutuhan selanjutnya akan digunakan untuk menentukan desain produk yang akan dikembangkan. Desain produk diwujudkan dalam bentuk gambar atau bagan, sehingga dapat digunakan sebagai pegangan untuk menilai dan membuatnya. Tahap desain produk kegitannya meliputi menentukan kompetensi dasar dan indicator, membuat flowchart dan storyboard, menyusun instrument penilaian media, menyusun butir soal 
dan kisi-kisi soal, dan menyusun rencana pelaksanaan pembelajaran (RPP). Materi bersumber dari buku ajar kelas VIII yang digunakan oleh guru di sekolah. Untuk pengumpulan bahan pendukung seperti gambar diperoleh melalui download di internet.

Ketiga Pengembangan (Development), Selanjutnya yaitu pengembangan media, tahap pengembangan adalah proses mewujudkan blueprint menjadi kenyataan. Yaitu pada tahap ini semua yang dibutuhkan atau yang akan mendukung proses pengembangan harus disiapkan (Darmawijoyo et al., 2019). Pengumpulan bahan berupa materi pelajaran yang diperlukan untuk membuat produk seperti materi pokok dan bahan pendukung seperti gambar. Materi bersumber dari buku guru dan buku siswa kelas VIII yang dipergunakan oleh sekolah serta browsing di internet. Untuk bahan pendukung seperti gambar-gambar diperoleh melalui download di internet. Seluruh materi, aspek pendukung digabungkan dalam satu produk multimedia pembelajaran interaktif secara utuh.

Keempat, Tahap Implementasi (Implementation), Kemudian dalam tahap ini hal yang dilakukan adalah penilaian media, setelah pembuatan multimedia pembelajaran interaktif selesai. Produk yang dihasilkan kemudian dilakukan beberapa hal sebagai berikut. (1) uji ahli yang dilakukan terhadap uji ahli isi pembelajaramn dan uji ahli media pembelajaran (2) dilakukan uji coba yang dilakukan terhadap uji coba perorangan, dan uji coba kelompok kecil. Dalam pelaksanaan uji coba lapangan, responden diberikan pretest da post-test dengan tujuan untuk mengukur efektivitas produk yang kembangkan.

Kelima, Tahap Evaluasi (Evaluation), Evaluasi adalah proses untuk melihat (melkukan evaluasi) apakah sistem pembelajaran yang sedang dibangun berhasil, sesuai dengan harapan pengembangan awal atau tidak (Sugihartini et al., 2018). Pada tahap ini maka dilakukan evaluasi formatif yang bertujuan untuk mmengumpulkan data tentang efektivitas media yang dikembangkan melalui uji ahli yaitu uji ahli isi pembelajaran dan uji ahli media pembelajaran yang keemudian dilakukan revisi sesuai dengan saran dan komentar. Setelah itu dilakukan uji coba produk terhadap uji coba perorangan, uji coba kelompok kecil, dan uji coba lapangan. Kemudian dilakukan revisi sebagai upaya penyempurnaan produk yang dikembangkan sehingga diperoleh produk akhir yang dapat digunakan oleh guru dalam proses belajar mengajar.

Dalam penelitian pengembangan ini digunakan dua teknik analisis data, yaitu analisis deskriptif dan analisis deskriptif. Analisis Deskriptif Kualitatif Menurut Agung (Agung, 2017) metode analisis deskriptif kualitatif yaitu suatu cara analisis/pengolahan data dengan jalan menyusun secara sistematis dalam bentuk kalimat/kata-kata, kategorikategori mengenai suatu objek (benda, gejala, variabel tertentu), sehingga akhirnya diperoleh kesimpulan umum. Teknik analisis deskriptif kualitatif ini digunakan untuk mengolah data hasil uji coba ahli isi bidang studi atau mata pelajaran, dan ahli media pembelajaran. Teknik analisis data ini dilakukan dengan mengelompokkan informasiinformasi dari data kualitatif yang berupa masukan, tanggapan, kritik dan saran perbaikan yang terdapat pada angket dan hasil wawancara. Kemudian hasil ini digunakan untuk merevisi produk yang dikembangkan.

Analisis deskriptif kuantitatif digunakan untuk mengolah data yang diperoleh melalui kuesioner dalam bentuk skor. Dan analisis data inferensial digunakan untuk mengetahui tingkat efektivitas produk terhadap hasil belajar siswa pada siswa kelas VIII di MTs At-Taufiq Singaraja menggunakan produk multimedia pembelajaran interaktif. Data uji coba kelompok sasaran dikumpulkan dengan menggunakan pretest dan posttest terhadap materi pokok yang diuji cobakan. 
Pengujian hipotesis dilakukan dengan analisis uji t berkorelasi. Analisis uji t berkorelasi memerlukan beberapa persyaratan analisis antara lain: Uji normalitas dilakukan untuk mengetahui apakah sebaran skor pada setiap variabel berdistribusi normal atau tidak, untuk itu dapat digunakan teknik Liliefors. Apabila selisih nilai yang terbesar lebih kecil dari kriteria nilai Liliefors, maka dapat disimpulkan bahwa sebaran data berdistribusi normal. Menurut Koyan (Koyan, 2012) adapun cara yang dapat dilakukan untuk menguji normalitas suatu data dengan teknik Liliefors yaitu sebagai berikut.(a) Urutkan data sampel dari kecil ke besar dan tentukan frekuensi setiap data. (b) Tentukan nilai $\mathrm{z}$ dari setiap data. (c) Tentukan besar peluang untuk setiap nilai $\mathrm{z}$ berdasarkan tabel $\mathrm{z}$ dan diberi nama $\mathrm{F}(\mathrm{z})$. (d) Hitung frekuensi kumulatif relatif dari setiap nilai $\mathrm{z}$ yang disebut dengan $\mathrm{S}(\mathrm{z}) \rightarrow$ Hitung proporsinya, kalau $\mathrm{n}=20$, maka setiap frekuensi kumulatif dibagi dengan n. Gunakan nilai L0 yang terbesar. (e) Tentukan nilai $\mathrm{L} 0=|\mathrm{F}(\mathrm{z})-\mathrm{S}(\mathrm{z})|$, hitung selisihnya, kemudian bandingkan dengan nilai Lt dari tabel Liliefors. (f) Jika L0< Lt, maka H0 diterima, sehingga dapat disimpulkan bahwa sampel berasal dari populasi yang berdistribusi normal.

Uji homogenitas dilakukan untuk mencari tingkat kehomogenan secara dua pihak yang diambil dari kelompok-kelompok terpisah dari satu populasi yaitu kelompok control dan kelompok eksperimen.

Kriteria pengujian tolak H0 jika Fhitung < Ftabel yang berarti sampel homogen. Uji dilakukan pada taraf signifikan $5 \%$ dengan derajat kebebasan untuk pembilang $\mathrm{n}_{1}-1$ dan derajat kebebasan untuk penyebut $\mathrm{n}_{2^{-}} 1$.

Teknik analisis yang digunakan untuk pengujian hipotesis adalah teknik analisis uji $\mathrm{t}$ berkorelasi atau dependen. Dasar penggunaan teknik uji t berkorelasi ini adalah menggunakan dua perlakuan yang berbeda terhadap satu sampel. Pada penelitian ini akan menguji perbedaan hasil belajar IPA sebelum dan sesudah menggunakan modul terhadap satu kelompok.

Hasil uji coba dibandingkan ttabel dengan taraf signifikan 0,05 (5\%) untuk mengetahui apakah ada perbedaan antara sebelum dan sesudah menggunakan multimedia pembelajaran interaktif.

H0: Tidak terdapat perbedaan yang signifikan hasil belajar siswa setelah menggunakan multimedia pembelajaran interaktif pada mata pelajaran IPS Terpadu kelas VIII di MTs At-Taufiq Singaraja tahun ajaran 2019-2020 dan sesudah menggunakan multimedia pembelajaran interaktif pada mata pelajaran IPS Terpadu kelas VIII di MTs At-Taufiq Singaraja tahun ajaran 2019-2020.

H1: Terdapat perbedaan yang signifikan hasil belajar siswa setelah menggunakan multimedia pembelajaran interaktif pada mata pelajaran IPS Terpadu kelas VIII di MTs At-Taufiq Singaraja tahun ajaran 2019-2020 dan sesudah menggunakan multimedia pembelajaran interaktif pada mata pelajaran IPS Terpadu kelas VIII di MTs At-Taufiq Singaraja tahun ajaran 2019-2020.

Keputusan: Bila thitung $\geq \mathrm{t}$ tabel maka $\mathrm{H} 0$ ditolak dan $\mathrm{H} 1$ diterima. Bila thitung $\leq$ dari ttabel, maka H0 diterima dan $\mathrm{H} 1$ ditolak. 


\section{HASIL DAN PEMBAHASAN}

Hasil dan pembahasan penelitian adalah sebagai berikut:

\section{HASIL}

Penelitian pengembangan ini menghasilkan produk multimedia pembelajaran interaktif di lengkapi dengan perangkat pembelajaran seperti RPP sebagai acuan pembelajaran. Pengembangan multimedia pembelajaran interaktif ini telah melewati beberapa uji coba validitas yang terdiri dari (1) Uji ahli isi pembelajaran, (2) Uji ahli media pembelajaran, (3) Uji coba perorangan, (4) Uji coba kelompok kecil, (5) Uji coba lapangan. Adapun hasil dari uji ahli dapat dilihat pada tabel di bawah ini.

Tabel 1. Persentase Hasil Pengembangan Multimedia Pembelajaran Interaktif

\begin{tabular}{clcc}
\hline No & \multicolumn{1}{c}{ Subjek Uji Coba } & Hasil Validitas (\%) & Kualifikasi \\
\hline 1 & Uji Ahli isi Pembelajaran & $96,00 \%$ & Sangat Baik \\
2 & Uji Ahli Media Pembelajaran & $78,00 \%$ & Baik \\
3 & Uji Coba Perorangan & $86,66 \%$ & Sangat Baik \\
4 & Uji Coba Kelompok Kecil & $94,33 \%$ & Sangat Baik \\
5 & Uji Coba Lapangan & $87,11 \%$ & Sangat Baik \\
\hline
\end{tabular}

Uji normalitas data dilakukan terhadap data 18 siswa dari hasil belajar siswa kelas VIII dengan menggunakan multimedia pemebelajaran interaktif dan hasil pretest dan postest dinyatakan telah terdistribusi dengan normal. Hal ini menunjukan bahwa sampel benar-benar berasal dari populasi yang berdistribusi normal, sehingga perbedaan yang terjadi memang akibat perlakuan bukan perbedaan yang ada pada sampel. Uji normalitas data dilakukan untuk memperlihatkan bahwa sampel benar-benar berasal dari populasi yang berdistribusi normal, sehingga perbedaan yang terjadi memang akibat perlakuan bukan perbedaan yang ada pada sampel. Uji normalitas dilakukan penyebaran soal tes pre-test dan post-test untuk mengetahui data hasil belajar siswa pada pembelajaran IPS Terpadu tentang kerjasama antar Negara-negara ASEAN yang terdiri dari dua tahapan yaitu, (1) Penyebaran soal tes sebelum menggunakan media modul (pretest), (2) Tahap penyebaran soal tes sesudah menggunakan media modul (posttest).

Tabel 2. Hasil Uji Normalitas Pretest dan Posttest

\begin{tabular}{ccccc}
\hline No. & Hasil Belajar & L0 & Lt & Ket \\
\hline 1. & Pretest & $-0,0358$ & 0,1840 & Normal \\
2. & Posttest & $-0,1113$ & 0,1726 & Normal \\
\hline
\end{tabular}

Hasil dari uji normalitas pretest diperoleh $\mathrm{LO}=-0,0358<\mathrm{Lt}=0,1840$ maka $\mathrm{H} 0$ diterima, sehingga dapat disimpulkan bahwa sampel berasal dari populasi yang berdistribusi normal. Hasil dari uji normalitas posttest diperoleh $\mathrm{L} 0=-0,1113<\mathrm{Lt}=$ 0,1726 maka H0 diterima, sehingga dapat disimpulkan bahwa sampel berasal dari populasi yang berdistribusi normal.

Setelah melewati tahapan uji normalitas selanjutnya adalah uji homogenitas. Uji homogenitas ini dimaksudkan untuk mencari bahwa dua atau lebih kelompok data sampel berasal dari populasi yang memiliki variasi yang sama. Berdasarkan Hasil perhitungan diperoleh varians pretest 173,2 dan varians posttest 33,02 . Untuk menguji homogenitas 
varians data sampel digunakan uji $\mathrm{F}$ dan memperoleh Fhitung Ftabel $\left(n_{1}-n_{2}-1\right)$ yaitu: Fhitung $(5,24) \leq$ Ftabel $(1,96)$ yang berarti sampel bersifat homogen yang artinya kelompok data sampel berasal dari populasi yang memiliki varians yang sama.

Tahap akhir dalam penelitian ini adalah uji efektivitas. Uji Efektivitas produk pengembangan multimedia pemebelajaran interaktif dalam penelitian ini diukur dengan memberikan lembar soal pilihan ganda terhadap 18 orang siswa kelas VIII di MTs AtTaufiq Singaraja melalui pretest dan posttest. Berdasarkan nilai pretest dan posttest 18 orang siswa tersebut, maka dilakukan uji-t untuk sampel berkorelasi.

Rata-rata nilai pre-test siswa adalah 64,44 dan rata-rata nilai posttest siswa adalah 90,83 yang berarti rata-rata nilai post-test siswa berada di atas KKM (Kriteria Ketuntasan Minimal) mata pelajaran IPS sebesar 75. Rata-rata pre-test lebih kecil dari rata-rata nilai post-test. Setelah dilakukan perhitungan secara manual diperoleh hasil $t_{\text {hitung }}$ sebesar 8,422 . Kemudian harga ttabel dengan $\mathrm{db}=n_{1}+n_{2}-2=18+18-2=34$ Harga $t_{\text {tabel }}$ untuk db 34 dan dengan taraf signifikan 5\% $(\mathrm{a}=0,05)$ adalah 2,042. Dengan demikian, harga $t_{\text {hitung }}>t_{\text {tabel, }}$, sehingga $\mathrm{H} 0$ ditolak dan $\mathrm{H} 1$ diterima. Berdasarkan kriteria pengujian ini. Maka dapat dinyatakan bahwa terdapat perbedaan yang signifikan (5\%) hasil belajar siswa sebelum dan sesudah menggunakan multimedia pembelajaran interaktif pada kelas VIII di MTs At-Taufiq Singaraja. Sehingga dapat diinterpretasikan bahwa multimedia pembelajaran interaktif efektif meningkatkan hasil belajar

\section{PEMBAHASAN}

Dalam penelitian pengembangan ini produk yang dihasilkan adalah multimedia pembelajaran interaktif untuk kelas VIII di MTs At-Taufiq Singaraja Multimedia ini dikembangkan untuk memfasilitasi siswa kelas VIII agar dapat belajar secara mandiri dan sesuai dengan kemampuan belajar masing-masing yang akan berpengaruh terhadap hasil belajarnya. Menurut Allison Paolini (Paolini, 2015) "Tiga sumber utama untuk penilaian keunggulan mengajar termasuk siswa, rekan kerja, dan guru. Siswa menyelesaikan evaluasi pada akhir semester untuk memberikan umpan balik formatif dan sumatif tentang kursus dan hasil-hasilnya”. Dalam penelitian ini multimedia yang dikembangkan memuat materi IPS terpadu dan disertai dengan gambar-gambar pendukung yang relevan dengan materi, sehingga saat siswa membaca materi, siswa juga dapat melihat langsung gambar yang diterangkan pada materi tersebut. Adapun tampilan multimedia dapat dilihat pada gambar dibawah ini.

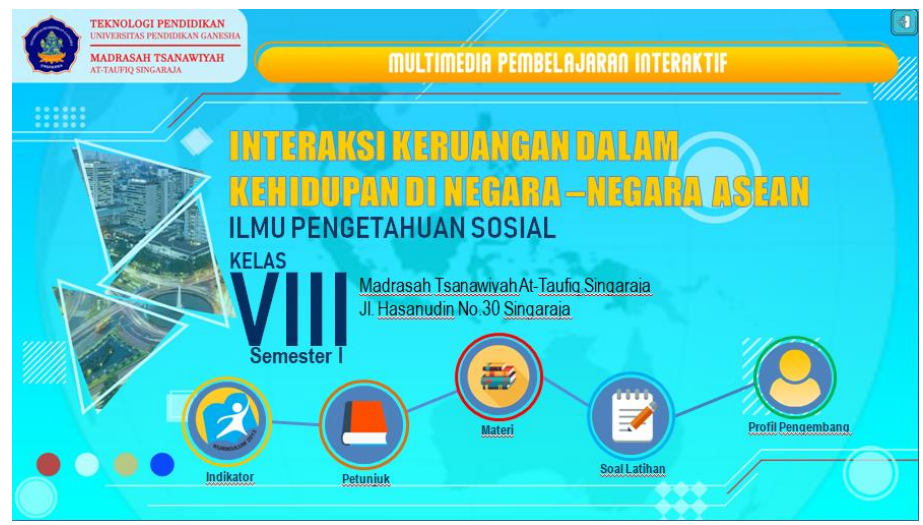

Gambar 2. Tampilan Menu Navigasi Multimedia Pembelajaran Interaktif (Sumber : Hasil Pengamatan Sendiri) 
Dalam pengembangannya, multimedia pembelajaran interaktif ini telah melewati beberapa tahap uji validitas dan uji coba serta perbaikan sesuai dengan masukan dan saran. Berikut ini akan dibahas hasil pengembangan multimedia berdasarkan hasil review dari ahli isi mata pelajaran, ahli media pembelajaran, uji coba perorangan, uji coba kelompok kecil, uji coba lapangan, dan pembahasan efektivitas multimedia pembelajaran interaktif.

Model pengembangan yang digunakan dalam penelitian ini adalah model ADDIE yang terdiri dari lima tahap yaitu, tahap analisis (Analysis), tahap desain (Design), tahap pengembangan (Development), tahap implementasi (Implementation), dan tahap evaluasi (Evaluation). Menurut Bamrara (Bamrara, 2017) model ADDIE pertama kali dikembangkan oleh Florida State University untuk pelatihan layanan personal militer dan selanjutnya diterapkan secara luas untuk bidang terkait lainnya yang paling banyak digunakan untuk pengembangan program pelatihan baru Instructional Design (ID). Dalam pendekatan ini menawarkan urutan sistem untuk mengevaluasi persyaratan peserta didik, desain dan pengembangan objek pelatihan, dan evaluasi kegunaan dari program pelatihan. Dalam penelitian pengembangan ini menghasilkan produk berupa multimedia pembelajaran interaktif. Multimedia yang dikembangkan ini menekankan siswa untuk belajar secara aktif dan termotifasi dalam mengikuti kegiatan belajar mengajar.

Hal tersebut sejalan dengan pendapat Amalia dkk. (dalam Divayana et al., 2016) yang menyatakan bahwa "Salah satu cara yang dapat digunakan untuk meningkatkan efektivitas dari proses pembelajaran adalah dengan membangun media pembelajaran interaktif". Media pembelajaran adalah segala sesuatu yang digunakan untuk menyalurkan pesan serta dapat merangsang pikiran, perasaan, perhatian, dan kemauan peserta didik sehingga dapat mendorong terjadinya proses belajar yang disengaja, bertujuan, dan terkendali serta terstruktur (Hakim \& Haryudo, 2014). Media merupakan sarana atau alat untuk menyampaikan informasi atau pesan dari suatu tempat ke tempat lain. Media digunakan dalam proses komunikasi termasuk kegiatan belajar mengajar. Pada hakikatnya proses belajar adalah proses komunikasi. Melalui proses komunikasi guru dapat menyampaikan pengalamannya atau pengetahuannya untuk dapat dipelajarai oleh anak didiknya. Namun tidak jarang kegiatan pembelajaran ini tidak berjalan dengan lancar, dan bahkan salah pengertian atau salah konsepsi. Untuk menghindari atau mengurangi terjadinya salah komunikasi maka digunakan media sebagai sarana pembelajaran.

Multimedia yang dikembangkan harus dapat memberikan kenyamanan kepada peserta didik guna untuk memberikan vasilitas dan motivasi dalam pembelajarannya. Dalam upaya memberikan vasilitas yang baik kepada peserta didik melalui multimedia tersebut maka multimedia yang dikembangkan harus mengandung beberapa komponen yang dapat mendukung pembelajaran peserta didiknya. Elemen atau komponen yang terkandung dalam multimedia, antara lain Teks, Grafis/Foto, Audio, Video, dan Animasi (Wijoyo, 2018).

Samura (Samura, 2015) menyatakan manfaat media dalam proses pembelajaran adalah memperlancar interaksi antar guru dengan siswa sehingga pembelajaran akan lebih efektif dan efisien. Namun secara lebih khusus ada beberapa manfaat media yang lebih rinci yaitu penyampaian materi pelajaran dapat diseragamkan, proses pembelajaran menjadi lebih jelas dan menarik, proses pembelajaran menjadi lebih interaktif, efisiensi dalam waktu dan tenaga, meningkatkan kualitas dan hasil belajar, media dapat 
memungkinkan proses belajar dapat dilakukan dimana saja dan kapan saja, media dapat menumbuhkan sikap positif siswat terhadap materi dan proses belajar, dan merubah peran guru kearah yang lebih produktif.

Validitas bahan ajar media pembelajaran merupakan suatu proses penilaian yang dilakukan pada sebuah produk/media untuk mengetahui produk/media tersebut valid atau tidak, sehingga dapat diketahui kelayakan media pembelajaran tersebut untuk digunakan pada proses pembelajaran (Ferdianto \& Setiyani, 2018). Dalam penelitian ini validitas media dilakukan terhadap 1) uji ahli isi mata pelajaran, 2) uji ahli media pembelajaran, 3) uji coba perorangan, 4) uji coba kelompok kecil, dan 5) uji coba lapangan. Hal ini sesuai dengan pendapat Suartama (Suartama, 2016) "evaluasi sumatif dilakukan melalui tinjauan ahli (expert review). Ahli yang mengevaluasi media adalah ahli isi, ahli desain pembelajaran, ahli media". Selain itu menurut Sadiman (Sadiman, 2012) "uji coba produk akan dilaksanakan dalam 3 (tiga) tahap yaitu uji coba perorangan, uji coba kelompok kecil, dan uji coba lapangan". Pembahasan uji coba produk adalah sebagai berikut.

Kualitas multimedia pembelajaran interaktif dilihat dari aspek isi mata pelajaran masuk dalam kategori sanga baik. Perolehan kualitas multimedia pembelajaran interaktif dengan kategori sangat baik dikarenakan multimedia ini telah menyajikan isi atau materi yang sesuai dengan tuntutan kompetensi inti, kompetensi dasar dan berasal dari sumbersumber yang relevan. Penentuan materi juga tidak telepas dari silabus dan RPP yang digunakan. Materi yang disajikan pada multimedia diintegrasikan dengan gambar-gambar sebagai penjelas dari materi yang dicakup. Di akhir penyajian isi atau materi telah disediakan soal latihan yang relevan dengan materi sebagai tolak ukur pemahaman siswa dalam mempelajari materi yang disajikan. Sedangkan dilihat dari aspek media pembelajaran menurut ahli media pembelajaran dinyatakan valid dengan kualifikasi baik. Kriteria baik yang didapatkan dari ahli media pembelajaran karena dalam pengembangan multimedia, peneliti memperhatikan konsistensi dari multimedia yang sesuai dengan indikator dan tujuan pembelajaran.

Multimedia yang dikembangkan setelah melewati hasil review dari para ahli, yaitu ahli isi, dan ahli media pembelajaran, kemudian produk diuji cobakan kepada siswa. Tahap uji coba ini terdiri dari uji coba perorangan, kelompok kecil dan uji coba lapangan. Kualitas multimedia pembelajaran interaktif pada uji coba perorangan, uji coba kelompok kecil dan uji coba lapangan menunjukkan bahwa multimedia memiliki kualifikasi sangat baik. Perolehan kualitas sangat baik ini karena multimedia mampu memotivasi siswa dalam mengikuti kegiatan belajar mengajar. Multimedia juga memuat gambar-gambar yang mendukung materi, sehingga siswa menjadi lebih mudah memahami isi materi yang diterangkan. Selain itu bahasa yang digunakan dalam multimedia pembelajaran interaktif ini juga mudah dipahami oleh siswa.

Multimedia pembelajaran harus dapat memberikan motivasi belajar kepada siswanya yang akan mempengaruhi hasil belajar dan kualitas belajarnya. Menurut Dimyanti (dalam Daud, 2012), motivasi dipandang sebagai dorongan meental yang menggerakkan dan mengarahkan perilaku manusia termasuk perilaku belajar. Dalam motivasi terkandung adanya keinginan yang mengaktifkan, menggerakkan, menyalurkan, dan mengarahkan sikap dan perilaku individu untuk belajar. Sedangkan hasil belajar merupakan kemampuan yang diperoleh individu setelah proses belajar berlangsung yang dapat memberikan perubahan tingkah laku baik pengetahuan, pemahaman, sikap dan keterampilan siswa sehingga menjadi lebih baik dari sebelumnya (Sjukur, 2012). 


\section{SIMPULAN DAN SARAN}

Terdapat 3 hal yang dapat disimpulkan dalam pengembangan multimedia interaktif pada mata pelajaran IPS terpadu ini yaitu: Pertama, Rancang bangun multimedia mengacu pada model pengembangan ADDIE yang terdiri dari 5 (lima) tahapan yaitu tahap analisis, tahap desain, tahap pengembangan, tahap implementasi, dan tahap evaluasi. Kedua, Agar multimedia pembelajaran interaktif dapat digunakan dalam proses pembelajaran maka dilakukan uji validitas terhadap uji ahli isi multimedia pembelajaran dan uji ahli media pembelajaran. Hasil dari uji validitas uji ahli isi multimedia pembelajaran mendapatkan nilai sangat daik sedangkan dari uji ahli media pembelajaran mendapatkan nilai baik dan kemudia dilakukan revisi sesuai masukan dan saran yang diberikan. Selanjutnya dilakukan uji coba terhadap uji coba perorangan, uji coba kelompok kecil, dan uji coba lapangan. Pada tahap uji coba multimedia yang dikembangkan mendapatkan respon baik dari peserta didik sehingga mendapat nilai yang sangat baik dan tidak perlu dilakukan revisi direvisi. Ketiga, dilakukan uji validitas berdasarkan hasil hitung uji-t terhadap nilai pretest dan posttest yang dilakukan terbukti bahwa multimedia pembelajaran interaktif dapat meningkatkan hasil belajar siswa pada mata pelajaran IPS Terpadu sehingga multimedia pembelajaran interaktif efektif digunakan dalam proses pembelajaran.

\section{DAFTAR PUSTAKA}

Agung, A. A. G. (2017). Metodologii Penelitian Pendidikan. Universitas Pendidikan Ganesha.

Angko, N., \& Mustaji. (2013). Pengembangan Bahan Ajar Dengan Model ADDIE untuk Mata Pelajaran Matematika Kelas 5 SDS Mawar Sharon Surabaya. Jurnal KWANGSAN, 1-15.

Bamrara, A. (2017). Applaying ADDIE Model to Evaluate Faculty Development Programme. Journal of Indian Education, 43(3).

Cahdriyana, R. A., \& Richardo, R. (2016). Karakteristik Media Pembelajaran Berbasis Komputer Untuk Siswa SMP. Journal of Mathematics Education, 1-11. http://jurnalnasional.ump.ac.id/index.php/alphamath/

Darmawijoyo, Marlina, E., \& Putri, R. I. I. (2019). Developing Problem High Order Thinking Type Aplication Volume Vube and Cuboid Based Learning for Secondary School. Intertional Journal of Active Learning. http://journal.unnes.ac.id/nju/index.php/ijal

Daud, F. (2012). Pengaruh Kecerdasan Emosional (EQ) dan Motivasi Belajar Terhadap Hasil Belajar Biologi Siswa SMA 3 Negeri Kota Palopo. Jurnal Pendidikan Dan Pembelajaran, 19(2), 243-255.

Diani, R., Yuberti, \& Syafitri, S. (2016). Uji Effect Size Model Pembelajaran Scramble Dengan Media Video Terhadap Hasil Belajar Fisika Peserta Didik Kelas X MAN 1 Pesisir Barat. Jurnal Ilmiah Pendidikan Fisika Al-BiRuNi, 265-275. http://www.ejournal.radenintan.ac.id/index.php/al-biruni/article/view/126

Divayana, D. G. H., Suyasa, P. W. A., \& Sugihartini. (2016). Pengembangan Media Pembelajaran Berbasis Web Untuk Matakuliah Kurikulum dan Pengajaran di Jurusan Pendidikan Teknik Informatika Universitas Pendidikan Ganesha. Jurnal 
Nasional Pendidikan Teknik Informatika (JINAPATI), 5(3), 149-157.

Ferdianto, F., \& Setiyani. (2018). Pengembangan Bahan Ajar Media Pembelajaran Berbasis Kearifan Lokal Mahasiswa Pendidikan Matematika. (Jurnal Nasional Pendidikan Matematika), 2(1), 37-47.

Hakim, B. R., \& Haryudo, S. I. (2014). Pengembangan Media Pembelajaran Interaktif Animasi Flash pada Standar Kompetensi Memasang Instalasi Penerangan Listrik Bangunan Sederhana di SMK Walisongo 2 Gempol. Jurnal Pendidikan Teknik Elektro, 3(1), 15-21.

Hayati, S., Budi, A. S., \& Handoko, E. (2015). Pengembangan Media Pembelajaran Flipbook Fisika untuk Meningkatkan Hasil Belajar Peserta Didik. Prosiding Seminar Nasional Fisika (e-Journal), 4.

Herawati, E. (2017). Upaya Meningkatkan Motivasi dan Hasil Belajar Siswa Menggunakan Media Pembelajaran Kartu Domino Matematika pada Materi Pangkat Tak Sebenarnya dan Bentuk Akar Kelas IX SMP Negeri Unggulan Sindang Kabupaten Indremayu. Jurnal Nasional Pendidikan Matematika, 1(1), 66-87. http://jurnal.unswagati.ac.id/index.php/JNPM/article/viewFile/254/200

Isya', M. A. (2017). Pengembangan model pembelajaran instruksional design dengan model Addie mata pelajaran PAI pada materi mengulang-ulang hafalan Surah Al Ma'un dan al Fil secara klasikal, kelompok dan individu kelas V SDN Gedongan 2 Kota Mojokerto. Jurnal Ilmiah Pendidikan Agama Islam, 7(1), 71-80. http://jurnal.stitradenwijaya.ac.id/index.php/tdb/article/view/37

Koyan, I. W. (2012). Statistik Pendidikan: Teknik Analisis data Kuantitatif. Universitas Pendidikan Ganesha.

Kurniawan, D., \& Dewi, S. V. (2017). Pengembangan Perangkat Pembelajaran dengan Media Screencast-O-Matic Mata Kuliah Kalkulus 2 Menggunakan Model 4-D Thiagarajan. Jurnal Siliwangi, 3(1), 214-219.

Mislan, \& Santoso, D. A. (2019). Peran Pengembangan Media Terhadap Keberhasilan Pembelajaran PJOK di Sekolah. Prosiding Seminar Nasional IPTEK Olahraga, 1216. https://ejournal.unibabwi.ac.id/index.php/semnassenalog/article/view/585

Novita, L., Rostikawati, R. T., \& Fitriani, K. A. (2020). Pengaruh Media Pembelajaran Kartu Bergambar Terhadap Hasil Belajar Subtema Organ Gerak Hewan. Jurnal Ilmiah Pendidikan, 04(01), 34-39. https://journal.unpak.ac.id/index.php/pedagonal/article/view/1992

Paolini, A. (2015). Enhancing Teaching Effectiveness and Student Learning Outcomes. The Journal of Effective Teaching, 15(1).

Qondiaas, D., Anu, E. L., \& Niftalia, I. (2016). Pengembangan Media Pembelajaran Tematik Berbasis Mind Maping SD Kabupaten Ngada Flores. Jurnal Pendidikan Indonesia, 5(2), 176-182.

Reyvalda, R., Rustandi, Y., \& Warnaen, A. (2019). Desain Media Penyuluhan Interaktif Berbasis Flash Player dengan Model ADDIE pada Materi Probiotik sebagai Pakan Aditif Sapi Perah. Jurnal Penyuluhan Pembangunan, 1(1), 64-70. https://jurnal.polbangtanmalang.ac.id/index.php/jppm/article/view/16

Sadiman, S. A. (2012). Media Pendidikan: pengertian, pengembangan dan pemanfaatanya. PT. Raja Grafindo Persada. 
Samura, A. O. (2015). Pengembangan Media dalam Pembelajaran Matematika dan Manfaatnya. Jurnal Matematika Dan Pendidikan Matematika, 4(1), 69-79.

Septiana, F. I. (2017). Peran Guru dalam Standar Proses Pendidikan Khusus Pada Lingkup Pendidikan Formal (Sekolah Luar Biasa/Sekolah Khusus). Journal of Special Education, 3(2), 131-139. http://ojs.uninus.ac.id/index.php/Inclusi/article/view/145

Sjukur, B. S. (2012). Pengaruh Blended Learning Terhadap Motivasi Belajar dan Haisl Belajar Siswa Tingkat SMK. Jurnal Pendidikan Vokasi, 2(3), 368-378.

Suartama, I. K. (2016). Bahan Ajar: Evaluasi dan Kriteria kualitas Multimedia Pembbelajaran. Universitas Pendidikan Ganesha.

Sugihartini, N., Yudiana, \& Kadek. (2018). Addie Sebagai Model Pengembangan Media Instruksional Edukatif (Mie) Mata Kuliah Kurikulum Dan Pengajaran. Jurnal PendidikanTeknologi Dan Jekuruan, 15(2), 277-286. https://ejournal.undiksha.ac.id/index.php/JPTK/article/view/14892

Surahman, E., \& Mukminan. (2017). Peran Guru IPS Sebagai Pendidik dan Pengajaran dalam Meningkatkan Sikap Sosial dan Tanggung Jawab Sosial Siswa SMP. Jurnal Pendidikan IPS, 4(1), 1-13.

Tegeh, I. M., \& Dkk. (2014). Model Penelitian Pengembangan. Graha Ilmu.

Widyastuti, I. (2017). Hubungan fasilitas belajar dan motivasi belajar terhadap hasil belajar PKN siswa kelas III SDN Gugus Dwija Harapan Kota Semarang. Joyful Learning Journal, 37-44.

Wijoyo, A. (2018). Pengaruh Hasil Belajar Siswa dengan Menggunakan Multimedia Pembelajaran Interaktiif untuk Sekolah Menengah Pertama dan Sekolah Menengah Atas. Jurnal Informattika Universitas Pamulang, 3(1), 46-55.

Wiphasith, H., Narumol, R., \& Sumale, C. (2016). The Design of The Contents of an eLearning for Teaching M.5 English Language Using ADDIE Model. International Journal of Information and Education Technology, 6(2).

Yudasmara, G. A., \& Purnami, D. (2015). Pengembangan Media Pembelajaran Interaktif Biologi untuk Meningkatkan Hasil Belajar Siswa SMP. Jurnal Pendidikan Dan Pembelajaran, 48(1-3), 1-8. 